\title{
IDENTIFIKASI KEMAMPUAN BERPIKIR KRITIS SISWA DALAM MENYELESAIKAN SOAL/ MASALAH MATEMATIKA PADA MATERI FAKTORISASI SUKU ALJABAR DI KELAS VIII SMP
}

\author{
Nur Qomariyah Nawafilah ${ }^{1}$ \\ ${ }^{1}$ Program Studi Teknik Informatika Fakultas Teknik Universitas Islam Lamongan \\ E-mail : nq.nawafil@yahoo.com
}

\begin{abstract}
ABSTRAK
Perkembangan ilmu pengetahuan dan teknologi menuntut kemampuan manusia untuk dapat menyaring informasi yang diterima. Oleh sebab itu manusia harus dapat berpikir kritis. Dalam dunia pendidikan, berpikir kritis dapat diajarkan melalui matematika, karena matematika merupakan sarana berpikir yang dapat menumbuhkembangkan daya nalar dan cara berpikir logis. Banyak cara untuk melatih siswa berpikir kritis, salah satunya adalah dengan menyelesaikan soal matematika yang membutuhkan berpikir kritis. Dengan cara tersebut diharapkan siswa akan terlatih untuk dapat menyelesaikan masalah dengan logis dan sistematis. Tujuan penelitian ini adalah untuk mendeskripsikan level kemampuan berpikir kritis siswa. Subjek penelitian adalah siswa kelas VIII-C SMP Negeri 1 Kediri yang terdiri dari 25 siswa. Siswa diberikan tes berpikir kritis kemudian dikategorikan ke dalam level 4 (kritis), level 3 (cukup kritis), level 2 (kurang kritis), level 1 (tidak kritis). Hasil penelitian ini menunjukkan bahwa siswa pada level 4 sebanyak 4 anak (16\%), level 3 sebanyak 8 anak (32\%), level 2 sebanyak 6 anak (24\%), dan level 1 sebanayk 7 anak (28\%).
\end{abstract}

Kata kunci : Berpikir Kritis, Matematika, Penyelesaian Masalah

\begin{abstract}
Developments in science and technology requires human ability to be able to filter the received information. Therefore, people must be able to think critically. In education, think critically can be teached by mathematics, it caused mathematics is means of thinking that can grow reasoning dan logical thinking ability. There are many ways to retread students to think critically, such as by solving mathematics problem that need critical thinking. By that way, hoped students will retreaded to be able to solve any problem logically and systematically. The objective of this research is to describe the level of students' critical thinking ability. Subjects of this research are students in class VIII-C of SMP Negeri 1 Kediri consisting of 25 students. They given critical thinking test then the results are categorized into $4^{\text {th }}$ level (critical), $3^{\text {rd }}$ level (critical enough), $2^{\text {nd }}$ level (less critical), and $1^{\text {st }}$ level (not critical). The result shows that there are 4 students in $4^{\text {th }}$ level $(16 \%), 8$ students in $3^{\text {rd }}$ level $(32 \%), 6$ students in $2^{\text {nd }} l e v e l$ (24\%), and 7 students in $1^{\text {st }}$ level (28\%).
\end{abstract}

Keywords: Critical Thinking, Mathematic, Problem Solving

\section{PENDAHULUAN}

Perkembangan teknologi yang sangat pesat sangat berpengaruh dalam dunia pendidikan. Berkembangnya teknologi ini juga mengakibatkan berkembangnya ilmu pengetahuan yang memiliki dampak positif maupun negatif. Pendidikan merupakan salah satu fondasi dari kemampuan ilmu pengetahuan dan teknologi (Buchori, 2001). Pembelajaran menjadi aspek yang sangat penting dalam pendidikan, sehingga perlu dikembangkan untuk lebih menggali potensi siswa dengan harapan akhir dapat menghasilkan lulusan yang berkualitas. Banyak hal yang dapat dikategorikan dalam siswa yang berkualitas, diantaranya adalah siswa yang kreatif, kritis, sistematis, logis, inovatif dan kemampuan bekerjasama.

Dalam pembelajaran matematika, berpikir kritis kini menjadi aspek yang terus 
dipacu dan ditumbuhkan pada diri siswa. Syukur (2005) menyatakan bahwa salah satu kemampuan yang penting untuk dikuasai oleh siswa adalah kemampuan berpikir kritis. Selama ini kemampuan berpikir kritis selalu dikaitkan dengan keberanian berpendapat dan mampu untuk berdebat di muka umum untuk menyampaikan argumen-argumen. Lebih dari itu berpikir kritis meliputi aspek di balik itu semua, termasuk aspek berpikir logis dalam matematika.

Rath et al (1966) menyatakan bahwa salah satu faktor yang dapat mempengaruhi perkembangan kemampuan berpikir kritis adalah interaksi antara pengajar dan siswa. Siswa memerlukan suasana akademik yang memberikan kebebasan dan rasa aman bagi mereka untuk mengekspresikan pendapat selama berpartisipasi dalam kegiatan pembelajaran. Salah satu komponen berpikir kritis yang perlu dikembangkan adalah ketrampilan intelektual. Ketrampilan intelektual merupakan seperangkat ketrampilan yang mengatur proses yang terjadi dalam benak seseorang.

Bloom mengelompokkan ketrampilan intelektual dari ketrampilan yang sederhana sampai yang kompleks, antara lain pengetahuan/ pengenalan, pemahaman, penerapan, analisis, sintesis, dan evaluasi. Ketrampilan menganalisis, mensintesis, dan mengevaluasi pada taksonomi Bloom merupakan ketrampilan pada tingkat yang lebih tinggi (Higher Order Thinking) (Cotton K.,1991). Kesepakatan yang diperoleh dari hasil lokakarya American Philosophical Association (APA, 1990) tentang komponen ketrampilan intelektual yang diperlukan pada berpikir kritis antara lain interpretation, analysis, evaluation, inference, explanation, dan self regulation (Duldt-Battey BW, 1997). Masing-masing komponen tersebut merupakan kompetensi yang perlu disusun dan disepakati oleh para guru tentang perilaku apa saja yang seharusnya dapat ditunjukkan oleh siswa pada tiap-tiap komponen di tiap-tiap tingkat sepanjang program pendidikan.

Seseorang yang memilki kemampuan memori yang baik dan mengetahui tentang banyak hal belum tentu cukup baik dalam berpikir kritis (Lau \& Chan, 2004). Dari pendapat tersebut menunjukkan bahwa seseorang yang mampu berpikir kritis, terampil dalam menggunakan pengetahuan dan intelegensinya. Sedangkan orang yang tahu banyak hal belum tentu mampu untuk menarik kesimpulan dari apa yang diketahuinya dan tahu bagaimana mengolah informasi tersebut untuk memecahkan masalah serta mencari sumbersumber informasi yang relevan bagi dirinya dan masalah yang dihadapi.

Menurut Garrison (dalam Filsaine, 2008:58) "Para pemikir kritis melewati lima tahap, yaitu mengidentifikasi masalah, mendefinisikan masalah dengan jelas, mengeksplorasi masalah dan solusi yang mungkin, mengevaluasi penerapannya dan mengintegrasikan pemahaman dengan pengetahuan yang ada". Dari pendapat Garrison dapat disimpulkan bahwa para pemikir kritis akan berpikir selangkah demi selangkah. Mereka akan melalui tahapan-tahapan berpikir kritis dalam menyelesaikan masalah.

Dari uraian di atas, peneliti menyimpulkan bahwa siswa yang berpikir kritis akan mampu: 1) membedakan informasi yang relevan dan yang tidak relevan, 2) mendeteksi kekeliruan dan memeperbaiki kekeliruan konsep, 3) menguji masalah secara terbuka, 4) menganalisis masalah, 5) memahami karakterisik suatu hal tertentu meskipun diubah bentuknya, 6) mengambil kesimpulan setelah seluruh fakta dikumpulkan dan dipertimbangkan.

Pembelajaran di sekolah menuntut siswa untuk berpikir kritis. Salah satu contoh penerapan berpikir kritis dalam pembelajaran adalah menyelesaikan soal matematika. Dalam menyelesaikan soal matematika siswa harus mencerna informasi yang termuat dalam soal, menganalisis soal, dan memodelkan soal ke dalam bentuk matematika. Salah satu permasalahan matematika yang dapat menggunakan aspek berpikir kritis adalah permasalahan yang muncul pada materi faktorisasi suku aljabar. Materi faktorisasi suku aljabar diajarkan kepada siswa kelas VIII SMP.

Dari uraian di atas peneliti memandang perlu untuk melakukan penelitian tentang berpikir kritis (critical thinking) dengan judul "Identifikasi Kemampuan Berpikir Kritis Siswa dalam Menyelesaikan Soal/ Masalah Matematika pada Materi Faktorisasi Suku Aljabar di Kelas VIII SMP”.

\section{METODE PENELITIAN}

Penelitian ini merupakan penelitian deskriptif kualitatif, di mana peneliti berusaha untuk mendeskripsikan kemampuan berpikir kritis siswa dengan mengunakan kriteria- 
kriteria yang ditetapkan oleh peneliti. Penelitian dilaksanakan di SMP Negeri 1 Kediri pada semester 1 tahun ajaran 2013-2014. Subjek penelitian ini adalah siswa kelas VIII-C yang terdiri atas 25 siswa.

Terdapat 3 kegiatan yang dilakukan dalam penelitian ini, yaitu kegiatan awal, kegiatan inti, dan kegiatan akhir. Pada kegiatan awal, aktivitas yang dilakukan adalah observasi kelas dan merancang instrumen penelitian. Pada kegiatan inti, aktivitas yang dilakukan adalah memberikan tes yang berupa soal matematika dan pada kegiatan akhir, data yang diperoleh selanjutnya dianalisis sesuai dengan metode analisis dan terakhir mengambil kesimpulan. Selanjutnya menyusun laporan berdasarkan hasil-hasil penelitian.

Teknik Pengumpulan data yang digunakan adalah metode tes. Tes yang digunakan dalam penelitian ini adalah uraian yang berbentuk soal cerita. Siswa diberi waktu pengerjaan soal selama 60 menit. Tes dilaksanakan setelah materi diajarkan. Hasil dari tes ini digunakan untuk mengklasifikasikan siswa ke dalam level kemampuan berpikir kritis.

Data yang diperoleh dari hasil tes selanjutnya dianalisis dengan langkah:

1. Hasil penyelesaian soal dianalisis dengan memperhatikan 6 karakteristik berpikir kritis. Untuk mengetahui karakter berpikir kritis $K_{1}$ (kemampuan unutk membedakan informasi yang relevan dan tidak relevan) dilakukan analisis terhadap soal nomor 3, untuk mengetahui karakter berpikir kritis $K_{2}$ (Kemampuan untuk mendeteksi kekeliruan dan memperbaiki kekeliruan konsep) dilakukan analisis terhadap soal nomor $1 \mathrm{c}$. $K_{2}$ terpenuhi jika siswa mampu memperbaiki konsep yang nampak pada soal dengan cara menerapkan konsep lain yang lebih tepat untuk menyelesaikan soal tersebut. Untuk mengetahui karakter berpikir kritis $K_{3}$ (Menguji masalah secara terbuka) dilakukan analisis terhadap soal nomor 2. Sedangkan untuk mengetahui karakter berpikir kritis $K_{4}$ (kemampuan untuk menganalisis masalah) dilakukan analisis terhadap soal nomor 4. Analisis untuk $K_{5}$ (kemampuan untuk mengambil keputusan/kesimpulan setelah seluruh fakta dikumpulkan dan dipertimbangkan) dan $K_{6}$ (kemampuan memahami karakteristik suatu hal yang diubah bentuknya) berturut-turut soal nomor $1 \mathrm{~b}$ dan $1 \mathrm{a}$.
2. Hasil pekerjaan siswa dianalisis untuk menemukan level yang dipenuhi oleh masing-masing siswa dengan ketentuan:

a. Soal nomor 1.a digunakan untuk mengetahui karakter berpikir kritis $K_{6}$. Jika siswa mampu mendeteksi perubahan bentuk soal yang dimanipulasi pada soal tersebut maka siswa memenuhi kriteria $K_{6}$.

b. Soal nomor 1.b digunakan untuk mengetahui karakter berpikir kritis $K_{5}$. Jika siswa dapat menyelesaikan soal 1.b untuk mengambil keputusan dan membuat kesimpulan yang merupakan jawaban dari permintaan soal, maka karakteristik $K_{5}$ terpenuhi.

c. Soal nomor 1.c digunakan untuk mengetahui karakter berpikir kritis $K_{2}$. Jika siswa mampu menganalisis hasil pekerjaan dalam menyelesaikan soal yang diberikan dan memperbaiki kesalahn konsep yang sengaja disediakan, maka siswa telah memenuhi karakter $K_{2}$

d. Soal nomor 2 digunakan untuk mengetahui karakter berpikir kritis $\mathrm{K}_{3}$. Jika siswa mampu menemukan metodenya sendiri untuk menyelesaikan masalah dengan banyak solusi maka siswa tersebut memenuhi $K_{3}$.

e. Soal nomor 3 digunakan untuk mengetahui karakter berpikir kritis $K_{l}$. Jika siswa mampu memilih dengan tepat informasi yang dibutuhkan untuk menyelesaikan soal cerita tersebut, maka siswa telah memenuhi $K_{l}$.

f. Soal nomor 4 digunakan untuk mengetahui karakter berpikir kritis $K_{4}$. Jika siswa mampu menganalisis soal dengan memecah soal yang kompleks menjadi bagian-bagian yang lebih mudah diselesaikan dan menemukan jawaban yang diharapakn maka siswa memenuhi kriteria $K_{4}$.

\section{HASIL DAN PEMBAHASAN}

Data hasil penelitian tes berpikir kritis dalam menyelesaikan soal matematika, dianalisis berdasarkan pada karakteristik berpikir kritis, yaitu $K_{1}, K_{2}, K_{3}, K_{4}, K_{5}$, dan $K_{6}$. Kemudian dari hasil tes tersebut siswa dikelompokkan ke dalam empat level kemampuan berpikir kritis, yaitu level kritis (level 4), level cukup kritis (level 3), level kurang kritis (level2), dan level tidak kritis (level 1). Adapun data yang diperoleh adalah sebagai berikut: 
Tabel 1. Hasil Tes Berpikir Kritis Siswa

\begin{tabular}{|c|c|c|c|c|}
\hline No & Nama Siswa & $\begin{array}{c}\text { Jenis } \\
\text { Kelamin }\end{array}$ & $\begin{array}{c}\text { Karakteristik Yang } \\
\text { Terpenuhi }\end{array}$ & Level \\
\hline 1 & ACS & $\mathrm{P}$ & $K_{1}, K_{3}, K_{5}$ & Level 3 \\
\hline 2 & ALF & $\mathrm{L}$ & $K_{1}$ & Level 2 \\
\hline 3 & AKK & $\mathrm{P}$ & $K_{3,} K_{6}$ & Level 2 \\
\hline 4 & AFZ & $\mathrm{P}$ & - & Level 1 \\
\hline 5 & BGR & $\mathrm{L}$ & $K_{1}, K_{2}, K_{3}, K_{4}, K_{5}$ & Level 4 \\
\hline 6 & DRA & $\mathrm{P}$ & $K_{3}, K_{6}$ & Level 2 \\
\hline 7 & DMS & $\mathrm{P}$ & - & Level 1 \\
\hline 8 & DNU & $\mathrm{P}$ & $K_{5,} K_{6}$ & Level 2 \\
\hline 9 & DIL & $\mathrm{P}$ & $K_{2,} K_{5}$ & Level 3 \\
\hline 10 & ERS & $\mathrm{L}$ & $K_{5}$ & Level 1 \\
\hline 11 & FOD & $\mathrm{P}$ & - & Level 1 \\
\hline 12 & HGM & $\mathrm{L}$ & $K_{3}$ & Level 1 \\
\hline 13 & IPD & $\mathrm{P}$ & $K_{1,} K_{3}, K_{5}, K_{6}$ & Level 2 \\
\hline 14 & LNR & $\mathrm{P}$ & $K_{1}, K_{2,} K_{3,} K_{5}, K_{6}$ & Level 4 \\
\hline 15 & LDR & $\mathrm{P}$ & $K_{1}, K_{3}$ & Level 3 \\
\hline 16 & MLM & $\mathrm{P}$ & $K_{1,} K_{2}, K_{3}, K_{5}, K_{6}$ & Level 4 \\
\hline 17 & NSB & $\mathrm{L}$ & $K_{1}, K_{2}, K_{3,} K_{5}, K_{6}$ & Level 4 \\
\hline 18 & $\mathrm{NAH}$ & $\mathrm{L}$ & $K_{5}$ & Level 1 \\
\hline 19 & OEI & $\mathrm{P}$ & $K_{1}, K_{3,} K_{5,} K_{6}$ & Level 3 \\
\hline 20 & RAP & $\mathrm{L}$ & $K_{1}, K_{5}$ & Level 3 \\
\hline 21 & SNR & $\mathrm{P}$ & - & Level 1 \\
\hline 22 & WAN & $\mathrm{L}$ & $K_{1}, K_{3}, K_{5}$ & Level 3 \\
\hline 23 & YNW & $\mathrm{P}$ & $K_{1,} K_{5}$ & Level 3 \\
\hline 24 & NDA & $\mathrm{L}$ & $K_{6}, K_{3}$ & Level 2 \\
\hline 25 & DML & $\mathrm{P}$ & $K_{1,} K_{3,} K_{6}$ & Level 3 \\
\hline
\end{tabular}

Dari data hasil tes berpikir kritis di atas, dapat diketahui persentase siswa yang berada pada level kritis, level cukup kritis, level kurang kritis, dan level tidak kritis. Adapun perhitungannya adalah sebagai berikut.

1. Pada level kritis terdapat 4 anak

Persentase $=\frac{4}{25} \times 100 \%=16 \%$

2. Pada level cukup kritis terdapat 8 anak

Persentase $=\frac{8}{25} \times 100 \%=32 \%$

3. Pada level kurang kritis terdapat 6 anak

Persentase $=\frac{6}{25} \times 100 \%=24 \%$

4. Pada level tidak kritis terdapat 7 anak

Persentase $=\frac{7}{25} \times 100 \%=28 \%$

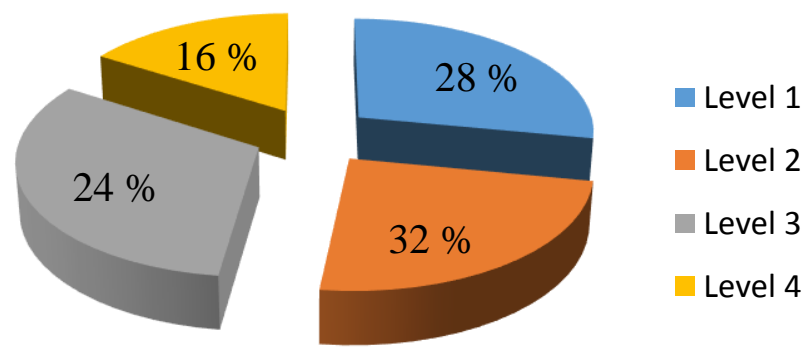

Gambar 1. Diagram level berpikir kritis kelas VIII-C

\section{KESIMPULAN}

Berdasarkan hasil analisis data, diperoleh kesimpulan bahwa kemampuan berpikir kritis siswa kelas VIII-C SMP Negeri 1 Kediri cenderung cukup kritis, karena sebagian besar (32\%) siswa berada pada level 3 atau level cukup kritis. Perincian banyaknya siswa yang memenuhi tiap-tiap level adalah $16 \%$ berada 
pada level kritis, $32 \%$ siswa berada pada level cukup kritis, $24 \%$ siswa berada pada level kurang kritis dan $28 \%$ siswa berada pada level tidak kritis.

Letak kelemahan berpikir kritis siswa dalam menyelesaikan soal matematika pada materi faktorisasi suku aljabar pada tiap level adalah sebagai berikut:

Pada level 4 (kritis): Siswa pada dasarnya sudah mampu memenuhi semua karakteristik berpikir kritis, namun beberapa masih memiliki kelemahan pada kriteria $K_{4}$, yaitu kemampuan dalam menganalisis masalah. Siswa kurang dapat memecah masalah kompleks menjadi bagian-bagian baru yang lebih sederhana untuk menemukan solusi yang lebih sederhana pula. Pada level 3 (cukup kritis): Siswa mengalami kesulitan pada karakteristik berpikir kritis memperbaiki konsep $K_{2}$ dan $K_{4} .7$ dari 8 siswa yang berada pada level ini tidak memenuhi kriteria $K_{2}$. Sebagian besar mereka masih terpaku pada satu konsep atau metode, dan masih kesulitan untuk mencoba menerapkan metode lain. Sedangkan untuk $\mathrm{K}_{3}$ samapi degan $\mathrm{K}_{6}$, masih cukup beragam.

Pada level 2 (kurang kritis): Kelemahan siswa pada level ini cukup beragam namun 2 dari 6 siswa yang berada pada level ini sudah dapat membedakan informasi yang relevan dan yang tidak relevan.

Pada level 1 (tidak kritis): Siswa sebagian besar memiliki kelemahan pada semua kriteria. 4 dari 7 siswa yang berada pada level ini tidak memenuhi semua kriteria yang ada.

\section{DAFTAR PUSTAKA}

Achmad, Arif. 2007. Memahami berpikir kritis . Tersedia di http://researchengines.com/1007arief3html.

Budi, Endah dkk. 2008. Contetual Teaching And Learning Matematika SMP kelas VIII. Jakarta : Pusat Perbukuan Departemen Pendidikan Nasional.

Filsaime, Dennis K. 2008. Menguak Rahasia Berpikir Kritis dan Kreatif. Jakarta: Presasi Pustakaraya.

Holili, M. 2008. Identifikasi Cara Berpikir Kritis dalam Menyelesaikan Soal/ Masalah Matematika pada Materi Fungsi Komposisi di SMA.

Ministry Of National Directorate General Of Management Of Primary And Secondary Education Directorate Of Junior High
School Development. 2008. Mathematics Student's Book For Junior High School Year VIII. Jakarta : Pusat Perbukuan Departemen Pendidikan Nasional

Nuharini, Dewi.2008, Matematika konsep dan aplikasinya, Jakarta: Pusat perbukuan, Departemen Pendidikan Nasional. 
Halaman ini sengaja dikosongkan 